Clinica Chimica Acta, 65 (1975) 75-78

(c) Elsevier Scientific Publishing Company, Amsterdam - Printed in The Netherlands

CCA 7367

\title{
PSEUDOCHOLINESTERASE IN THE SERUM OF ALLERGIC SUBJECTS
}

\author{
L. BERRENS and A.G. VAN DIJK \\ Division of Experimental Allergy, Academic Hospital, Catharijnesingel 101, Utrecht \\ (The Netherlands)
}

(Received June 11, 1975)

\section{Summary}

'I'here are no differences, between human normal and allergic sera, in the total activity of naphthylacetate-hydrolysing enzymes. No abnormal dibucaineinhibited isoenzymes were detected. The Michaelis constants and the activation energies of serum pseudocholinesterases in the sera of patients with atopic disease, urticaria, or extrinsic allergic alveolitis were within the normal range.

\section{Introduction}

According to the theory of Szentivanyi [1], the atopic condition in man is a partial impairment of the $\beta$-adrenergic receptors. Alternatively, it has been suggested that the increased parasympathetic tone in atopic people may be ascribed to overstimulation of the $\alpha$-adrenergic receptors [2]. As pointed out by Cotton et al. [3], a possible defect of this nature might be impaired functioning of the enzyme acetylcholinesterase. According to Chlebarov [4], the blood levels of acetylcholine in children with atopic asthma or neurodermatitis are directly in relation to the severity of the disease, though serum cholinesterase levels were normal. Cotton et al. [2,3] were unable to provide evidence for a functional abnormality of acetylcholinesterase (EC 3.1.1.7) in the skin of atopic patients, or of pseudocholinesterase (EC 3.1.1.8) in the blood plasma. Since the number of patients investigated was limited, pseudocholinesterase levels were determined in an extended group of atopic sera in the present work. The sera of patients with allergic disease not associated with atopy, i.e. extrinsic allergic alveolitis and urticaria, were also included in this study. The dibucaine number was determined [5] in order to detect possible isoenzyme abnormalities.

Materials and methods

Blood samples of adult allergic patients were submitted to the laboratory for the estimation of immunological parameters. The clinical conditions of 
bronchial asthma, atopic dermatitis and hay fever are collectively referred to as atopic disease. Cases of farmer's lung, pigeon-breeder's disease and allergic aspergillosis are grouped in the category extrinsic allergic alveolitis. The group urticaria includes all forms of urticaria and Quincke oedema of whatever aetiology. Sera from patients with alopecia areata were investigated because the condition is considered to feature a high incidence of atopy [6,7]. The serum samples were kept deep frozen at $-90^{\circ} \mathrm{C}$ until use.

Serum pseudocholinesterase was determined by the kinetic method of Zapf and Coghlan [8] without modification, using 1-naphthylacetate as a substrate. The cuvette housing used for 1-naphthol estimation was thermostatted at $25^{\circ} \mathrm{C}$; the absorbance was recorded at $321 \mathrm{~nm}$. The enzyme activities and degree of inhibition were expressed in units as recommended by the above authors.

\section{Results}

\section{Total activity and dibucaine number}

The kinetic method developed by Zapf and Coghlan [8] is a very useful technique for the rapid colorimetric estimation of the total level of 1-naphthylacetate splitting enzymes and for the assessment of possible abnormal genetic types by means of dibucaine inhibition. In our har. As, the coefficient of variation was $3.0 \%$. The mean value in normal blood donors was reported by Zapf and Coghlan to be $1.07 \mathrm{units} / \mathrm{ml} / \mathrm{min}$ for the enzyme activity, S.D. $=0.21$; the mean dibucaine number was $83 \%$, S.D. $=3 \%$. As shown in Table I, these values were slightly, though not significantly higher in our control group. The mean values for the groups of sera from patients with atopic diseases, extrinsic allergic alveolitis and urticaria were well within the normal range, both as regards total enzyme activities and dibucain inhibition. Among the total series of 88 samples investigated, only two sera produced abnormal values, viz. a significantly elevated serum enzyme activity in one case of alopecia areata (2.53 units) and a depressed dibucaine number in a case of factitious urticaria $(65 \%)$.

\section{Enzyme characteristics}

To detect possible aberrations in enzymatic functioning, the Michaelis

TABLE I

MEAN VALUE OF 1-NAPHTHYLACETATE HYDROLASE ACTIVITY $\triangle$ ND DIBUCAIN INHIBITION IN THE SERA OF ALLERGIC INDIVIDUALS

Units according to Zapf and Coghlan [8].

\begin{tabular}{|c|c|c|c|c|c|c|}
\hline \multirow[t]{2}{*}{ Group diagnosis } & \multicolumn{3}{|c|}{ Total activity } & \multicolumn{3}{|c|}{ Dibucaine numbers } \\
\hline & $N$ & $\begin{array}{l}\text { Mean } \\
\text { (units/ml/minl) }\end{array}$ & S.D. & $N$ & $\begin{array}{l}\text { Mean } \\
(\%)\end{array}$ & S.D. \\
\hline Atopic disease & 14 & 1.21 & 0.27 & 13 & 85 & 3 \\
\hline Extr. allergic alveolitis & 26 & 1.08 & 0.25 & N.D. & & \\
\hline Urticaria & 15 & 1.26 & 0.22 & 12 & 85 & 7 \\
\hline Alopecia areata & 20 & 1.30 & 0.34 & 20 & 86 & 2 \\
\hline Normal controls & 13 & 1.23 & 0.22 & 13 & 87 & 4 \\
\hline
\end{tabular}


TABLE II

ENZYME CHAR ACTERISTICS IN SOME SELECTED SERA

\begin{tabular}{llllll}
\hline Diagnosis & $\begin{array}{l}\text { Serum } \\
\text { No. }\end{array}$ & $\begin{array}{l}\text { Total activity } \\
(U / \mathrm{min} / \mathrm{ml})\end{array}$ & $\begin{array}{l}\text { Dibucaine } \\
\text { number }\end{array}$ & $\begin{array}{l}K_{\mathrm{m}} \\
(\mathrm{mmol} / \mathrm{l})\end{array}$ & $\begin{array}{l}V_{\max } \\
(\mathrm{U} / \mathrm{min} / \mathrm{ml})\end{array}$ \\
\hline Atopy & 74041 & 1.51 & N.D. & 0.61 & 3.00 \\
& 74039 & 1.25 & 82 & 0.59 & 2.50 \\
Extr. allergic alveolitis & 74027 & 1.23 & N.D. & 0.74 & 2.88 \\
& 74026 & 1.00 & 85 & 0.56 & 2.22 \\
Urticaria factitia & 74288 & 1.05 & 65 & 0.74 & 2.88 \\
Alopecia areata & 74265 & 1.24 & 85 & 0.74 & 3.22 \\
& 74258 & $\mathbf{2 . 3 2}$ & 87 & 0.91 & 6.43 \\
\hline
\end{tabular}

constants $K_{\mathrm{m}}$ and also $V_{\mathrm{max}}$ were established in a selected number of sera. These parameters were obtained from Lineweaver-Burk plots constructed in the substrate concentration range $1.5 \times 10^{-4} \mathrm{M}$ to $0.9 \times 10^{-3} \mathrm{M}$. As demonstrated by the examples collected in Table II, no significant variations were detected among the sera of patients with atopic or non-atopic allergies. Only the one case of alopecia areata must have contained an exceptionally active enzyme, but this defect was not typical of the condition. The $K_{\mathrm{m}}$ values found were 10 times lower than those reported by Cotton et al. [2], who used 2-naphthylacetate as a substrate.

The energy of activation was evaluated between $10^{\circ} \mathrm{C}$ and $30^{\circ} \mathrm{C}$, at $0.6 \times$ $10^{-3} \mathrm{M}$ substrate concentration, in 5 different sera, viz. alopecia areata (exceptional case, Table II), 2 cases of atopic allergy, 1 case of allergic interstitial pneumonitis and 1 healthy control. Values were calculated from the slope of Arrhenius plots of the observed reaction velocities and were found to be exactly identical at $5.65 \mathrm{kcal} / \mathrm{mol}$.

No inhibition was observed under the conditions of assay by highly purified house dust allergen, fraction $E$, in normal or allergic sera [9]. Though the $\beta$-blocking agent propanolol was found to be a powerful cholinesterase inhibitor, no differences could be detected in the apparent inhibitor constants in normal and allergic sera.

\section{Monthly variation}

Monthly serum samples were obtained from two volunteers suffering from allergic disease (hay fever/animal dander sensitivity and house dust allergy, respectively). Values for total 1-naphthylacetate hydrolase activity and the dibucain number varied little among a series of 12 sequential monthly samples. The sera of both patients displayed highest values of pseudocholinesterase activity in October, with a minimum in November, but differences remained within the expected experimental variation range.

\section{Discussion}

In conformation of the results of other authors $[2,3]$, the estimation of serum pseudocholinesterase and its dibucaine-inhibitable genetic variants is of no value in the study of allergic disease, atopic or non-atopic. However, the 
possibility cannot be excluded that minor differences are obscured by the activities of other carboxylic ester hydrolases which abound in human serum. Electrophoretic separation in polyacrylamide gel shows that naphthylacetate hydrolysing enzymes occur in multiple forms. It is quite conceivable that different functional characteristics may be detected among individual isoenzymes in human normal and allergic sera, as has been described for lactate dehydrogenase in patients with asthma [10]. Our studies, however, confirm that there is little sense in the routine determination of total serum pseudocholinesterase or its dibucaine-inhibited forms in allergic conditions. Experiments in progress demonstrate that the enzyme activities measurable in serum may be augmented by preincubation with atopic allergens. The possibility that the ease and mode of activation of 'silent' pre-enzymes by allergens will permit a distinction between atopic and non-atopic people requires further investigation.

\section{References}

1 A. Szentivanyi, J. Allergy, 42 (1968) 203

2 D.W.K. Cotton, J.J.M.A. Van der Hurk and P.D. Mier, Br. J. Dermatol., 88 (1973) 575

3 D.W.K. Cotton, J.J.M.A. Van der Hurk and P.D. Mier, Br. J. Dermatol., 88 (1973) 579

4 S. Chlebarov, Arch. Dermatol. Forsch., 244 (1972) 338

5 W. Kalow and K. Genest, Can. J. Biochem. Physiol., 35 (1957) 339

6 T. Ikeda, Dermatologica, 131 (1965) 421

7 A.J.P. Penders, Dermatulogica, 136 (1968) 395

8 P.W. Zapf and CH.M. Coghlan, Clin. Chim. Acta, 43 (1974) 337

9 L. Berrens, Progr. Allergy, 14 (1970) 259

10 D.J. Usher, R.J. Shepherd and T. Deegan, Thorax, 29 (1974) 685 